\title{
Analysis of Structure and Diversity of the Kilengwe Forest in the Morogoro Region, Tanzania
}

\author{
David Sylvester Kacholi \\ Department of Biological Sciences, Dar es Salaam University College of Education (DUCE), P.O. Box 2329, Dar es Salaam, Tanzania \\ Correspondence should be addressed to David Sylvester Kacholi; kacholi78@yahoo.com
}

Received 3 September 2013; Accepted 14 November 2013; Published 23 January 2014

Academic Editor: James T. Anderson

Copyright ( 2014 David Sylvester Kacholi. This is an open access article distributed under the Creative Commons Attribution License, which permits unrestricted use, distribution, and reproduction in any medium, provided the original work is properly cited.

\begin{abstract}
This study investigates the structure, species composition, and diversity of a section of the Kilengwe Forest in Tanzania. In order to accomplish the proposed objectives, 18 plots of $20 \mathrm{~m} \times 20 \mathrm{~m}$ were randomly established in the forest and the number of tree species in each plot was identified and counted. The most important families and species were determined using importance value indices at the respective taxonomic levels. Diversity was measured using the Shannon-Wiener and Fisher alpha diversity indices. A total of 276 stems/ha representing 93 species/ha within 26 families were documented from 0.72 ha. Fabaceae and Julbernadia globiflora were the dominant family and species, respectively. Seventy-eight percent of the total species were rare. The average basal area of the forest was $7.1 \mathrm{~m}^{2} /$ ha. The Shannon-Wiener index (4.02) and Fisher's alpha diversity (35.5) indicated high species diversity within the forest. The species-area and species-abundance curves revealed an escalating trend implying that more sampling efforts could result in a higher number of species existing in the forest. The size class distribution displayed a reverse J-shaped pattern; however, the larger size classes DBH $>50 \mathrm{~cm}$ were not represented. The study suggests the necessity for anthropogenic disturbance control as this is the major source of forest degradation in the studied area.
\end{abstract}

\section{Introduction}

Globally, $52 \%$ of the total forests are in tropical regions and they are known to be the most important areas in terms of biodiversity [1]. Local communities living nearby depend on these forests for their livelihoods. For instance, forest trees provide resources like food, traditional medicine, energy, timber, shade, and habitats for other organisms [2]. The rapid increase in human population near forest ecosystems has increased threats of degradation and fragmentation to these ecosystems [3]. In Tanzania, the rate of population increase per year is $2.7 \%$ with the majority of people living in rural areas where forests are located. The annual loss of forest cover in the country has increased by $37 \%$ from the period of 1990-1995 (322,000 ha/year) to 2000-2010 (403,000 ha/year). The loss is mainly due to agricultural clearings, overgrazing, charcoaling, firewood, and timber harvesting $[3,4]$. Like other tropical forests in the world, the Kilengwe Forest suffers extensive loss and degradation from anthropogenic activities and sporadic fire, which have a strong effect on the structure and species composition of the forest [5]. The quantification of the structure and diversity of tree species is important since they provide resources and habitat for a number of other species. Being the dominant life form in forests, trees are easy to locate specifically and count [6] and are comparatively better known from a taxonomic perspective [7]. Understanding tree composition and structure of forest is a vital instrument in assessing the sustainability of the forest, species conservation, and management of forest ecosystems. At the current study area, a few unpublished inventories have been recorded. Thus, the objectives of this study are to (i) identify inventory tree species composition and richness in Kilengwe Forest and compare them with other forests, locally and worldwide, and (ii) examine forest structure and composition patterns in the forest in terms of density, basal area, and size class distribution.

\section{Material and Methods}

2.1. Description of the Study Area. The Kilengwe Forest Reserve is found in Kisaki Ward, Bwakira Chini Division, 
in the Morogoro Rural District. It is owned by local government and surrounded by the villages of Kilengwe and Zongomero. The forest is situated at latitude $7^{\prime} 29^{\circ}$ South and longitude $37^{\prime} 32^{\circ}$ East at an elevation of 182 to $228 \mathrm{~m}$ above mean sea level covering an area of 995 ha. A number of seasonal streams that provide water to the local community for domestic purpose originate from the forest reserve. The climate of the region is oceanic due to proximity (about $200 \mathrm{~km}$ ) to the Indian Ocean and the rainfall regime is bimodal. The long rains last from March to May peaking in April while the short rains last from October to December. The mean annual rainfall and temperature in the Morogoro region are about $740 \mathrm{~mm}$ and $25.1^{\circ} \mathrm{C}$, respectively (10 years data up to 2010 were provided by the Morogoro Meteorological Station). Agriculture is the major socioeconomic activity carried out by locals living in the two neighboring villages.

2.2. Field Sampling. The tree sampling for the collection of data was performed in a random fashion in 18 plots of $20 \mathrm{~m}$ $\times 20 \mathrm{~m}$ each placed from the forest edge (100 $\mathrm{m}$ from forest margin) to the interior. In each plot, all trees with diameter at breast height $(\mathrm{DBH}) \geq 10 \mathrm{~cm}$ measured at $1.3 \mathrm{~m}$ above the ground were counted, identified, and $\mathrm{DBH}$-recorded. Trees with multiple stems at $1.3 \mathrm{~m}$ height were treated as a single individual and the diameters of all stems were obtained and averaged. If a tree had buttresses or abnormalities at $1.3 \mathrm{~m}$ height, the diameter was measured just above the buttress and the stem was assumed to have a cylindrical shape.

2.3. Data Analysis. The forest structure was described in terms of tree density (stems/ha), basal area $\left(\mathrm{m}^{2} / \mathrm{ha}\right)$, and size class distributions (SCDs). The tree density was calculated using the number of individuals divided by sample area while the basal area was equal to $0.00007854 \times D^{2}(D=\mathrm{DBH}$ in $\mathrm{cm})$. Four tree size or $\mathrm{DBH}$ classes were formed, each arranged in $10 \mathrm{~cm}$ intervals. The dominance of family and species was calculated based on Family Importance Value Index (FIV) [8] and the Species Importance Value Index (IVI) [9]. Species richness was expressed by the number of observed species in the forest while two non-parametric richness estimators (Michaelis-Menten (MMMeans) and first-order Jackknife) were used to estimate potential species richness [10]. The species accumulation curves based on number of individuals and sampled area were constructed for comparing the increase of number of species with increasing individuals and sample size, respectively [10]. Shannon-Wiener's, Fisher'salpha diversity, and Pielou's evenness were calculated using the Species Diversity and Richness IV (SDR IV) Software. The ratio of the number of individuals to the number of species (N/S) was also calculated [11].

\section{Results}

3.1. Floristic Composition and Importance Value. A total of 199 trees (276 stems/ha) representing 67 species (93 species/ha) belonging to 54 genera and 26 families were identified from 0.72 ha. Fabaceae was the dominant family in the forest with 21 species, followed by Moraceae (five species)

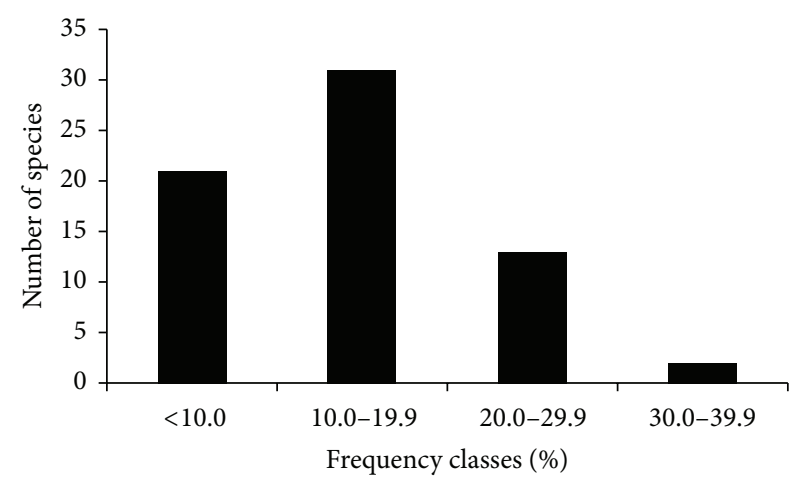

FIGURE 1: Frequency distribution of the tree species recorded in the present study.

and Sterculiaceae (four species). Within the family Fabaceae, the genera Acacia and Albizia were represented by four and three species, respectively. Of the total recorded families, $46 \%$ and $31 \%$ were comprised by species singletons and doubletons, respectively, whereas, $23 \%$ had more than two species. Of all recorded species, Julbernadia globiflora and Brachystegia spiciformis were the most frequent and abundant species, whereas $78 \%$ were rare with lower frequency (see Figure 1). The maximum Family Importance Value (FIV) was observed for Fabaceae (115.7) followed by Moraceae (21.0), Sterculiaceae (18.3), Bignoniaceae (13.5), Sapotaceae (13.3), and Combretaceae (10.9). The remaining 20 families had FIV values lower than 10.0 (Table 1). The top ten families accounted for $76 \%$ of the overall FIV. J. globiflora was the species with highest IVI value of 13.3, followed by Dalbergia melanoxylon (11.5), B. spiciformis (11.0), and Burkea africana (10.2) while the remaining 63 species had IVI of less than 10.0 (Table 2). The top ten species accounted for $30 \%$ of the overall IVI.

3.2. Tree Density and Basal Area. A total of 199 individuals ( 276 stems/ha) were recorded in the 0.72 ha study area. The family Fabaceae accounted for $37.2 \%$ of the total individuals, followed by Sterculiaceae (6.5\%) and Moraceae (6.0\%). Among the members of the family Fabaceae, B. spiciformis (with $11.0 \%$ of the total individuals), J. globiflora (11\%), and B. africana $(9.3 \%)$ were the most abundant species. Apart from Fabaceae members, only Synsepalum cerasiferum, a Sapotaceae, had $3.5 \%$ relative density while the remaining species had lower relative densities (Table 2). Of the recorded families, only Simaroubaceae and Phyllanthaceae were represented by one individual ( $0.5 \%$ relative density) while Apocynaceae, Meliaceae, Tiliaceae, and Rhizophoraceae had two individuals (1.0\%). Also, $28 \%$ and $24 \%$ of the total species were represented by one and two individual stems, respectively. The mean basal area of the studied plots in the forest was $7.1 \mathrm{~m}^{2} /$ ha (Table 3 ). Of this, members of the family Fabaceae constituted $47.2 \%$ of the total basal area, followed by Moraceae and Sterculiaceae with $7.5 \%$ and $5.8 \%$, respectively (Table 1). D. melanoxylon and J. globiflora were dominant and co-dominant having $8.1 \%$ and $6.0 \%$ of the total basal area (Table 2). 
TABLE 1: Family Importance Index Values for the studied plots in the Kilengwe Forest (RDi: relative diversity, RDe: relative density, RDo: relative dominance, and FIV: Family Importance Value).

\begin{tabular}{|c|c|c|c|c|}
\hline Family & RDi & RDe & RDo & FIV \\
\hline Fabaceae & 31.3 & 37.2 & 47.2 & 115.7 \\
\hline Moraceae & 7.5 & 6.0 & 7.5 & 21.0 \\
\hline Sterculiaceae & 6.0 & 6.5 & 5.8 & 18.3 \\
\hline Bignoniaceae & 4.5 & 5.5 & 3.5 & 13.5 \\
\hline Sapotaceae & 4.5 & 5.0 & 3.8 & 13.3 \\
\hline Combretaceae & 4.5 & 3.5 & 2.9 & 10.9 \\
\hline Loganiaceae & 3.0 & 3.5 & 2.9 & 9.4 \\
\hline Annonaceae & 3.0 & 3.5 & 2.7 & 9.2 \\
\hline Euphorbiaceae & 3.0 & 2.0 & 3.1 & 8.1 \\
\hline Clusiaceae & 3.0 & 1.5 & 3.2 & 7.7 \\
\hline Araliaceae & 3.0 & 2.0 & 1.8 & 6.8 \\
\hline Boraginaceae & 1.5 & 2.5 & 2.8 & 6.8 \\
\hline Burseraceae & 3.0 & 1.5 & 1.2 & 5.7 \\
\hline Rubiaceae & 3.0 & 1.5 & 0.9 & 5.4 \\
\hline Verbenaceae & 1.5 & 2.5 & 1.3 & 5.3 \\
\hline Anacardiaceae & 1.5 & 2.5 & 1.1 & 5.1 \\
\hline Ebenaceae & 1.5 & 2.5 & 1.1 & 5.1 \\
\hline Sapindaceae & 1.5 & 2.0 & 1.4 & 4.9 \\
\hline Ulmaceae & 1.5 & 2.0 & 1.2 & 4.7 \\
\hline Apocynaceae & 3.0 & 1.0 & 0.4 & 4.4 \\
\hline Meliaceae & 1.5 & 1.0 & 1.6 & 4.1 \\
\hline Salicaceae & 1.5 & 1.5 & 1.0 & 4.0 \\
\hline Tiliaceae & 1.5 & 1.0 & 0.7 & 3.2 \\
\hline Rhizophoraceae & 1.5 & 1.0 & 0.4 & 2.9 \\
\hline Simaroubaceae & 1.5 & 0.5 & 0.3 & 2.3 \\
\hline Phyllanthaceae & 1.5 & 0.5 & 0.2 & 2.2 \\
\hline Total & 100 & 100 & 100 & 300 \\
\hline
\end{tabular}

3.3. Species Richness, Diversity, and Species Accumulation Curves. The species richness of 67 species was observed in 0.72 ha of the Kilengwe Forest, whereas, the MMMeans and Jackknife 1 richness estimators provided the estimate of 124 and 86 species, respectively. The Fisher's alpha, ShannonWiener diversity, and evenness index values of 35.50, 4.02, and 0.95 were recorded, respectively. The ratio of the number of individuals to the number species $(\mathrm{N} / \mathrm{S})$ in the studied plots was 2.97 (see Table 3). The species accumulation curves showed an increasing trend as the number of individuals and sample plots increase (Figure 3).

3.4. Size Class Distribution. The tree size class distribution in the forest (Figure 3) exhibited the hypothetical negative exponential curve; however, the higher size classes $(>50.0 \mathrm{~cm})$ were not represented in this study. About $95.5 \%$ of the recorded stems were in the first (77.4\%) and in the second (18.1\%) size classes whereas the midsize classes, $30.0-39.9 \mathrm{~cm}$ and $40.0-49.9 \mathrm{~cm}$, were represented by $2.5 \%$ and $2.0 \%$, respectively. The maximum DBH value was $46.6 \mathrm{~cm}$ recorded for D. melanoxylon, followed by $46.1 \mathrm{~cm}$ of Milicia excelsa.

\section{Discussion}

4.1. Floristic Composition, Diversity, and Richness. The species richness of 93 species/ha is considerably higher compared to the range of $8-66$ species/ha recorded by Malimbwi et al. [12] in some forests of Morogoro. The recorded species richness is within the range of 24-122 species/ha obtained in the Budongo Forest in Uganda [13] and is similar to the results from Doody et al. [14] who observed 100 species/ha in the Mpanga Forest in Tanga Region, Tanzania. However, the value is lower compared to Amazonian forests, for which up to 283 species/ha have been recorded [15]. In fact, the comparisons between different studies may be an inadequate strategy since different methodology has been used in different cases. For example, the sizes of the plots vary greatly among studies and this has a strong effect on the results obtained. The dominance of family Fabaceae in terms of FIV (Table 1) was mainly due to high species richness, abundance, and basal area of the constituent species. The family Fabaceae is known to dominate the tropical lowland forests $[15,16]$. For instance, various authors (e.g., $[2,17,18]$ ) have reported this family being dominant in the coastal forests of Tanzania 
TABLE 2: Species Importance Index Values for the studied plots in the Kilengwe Forest (Rf: relative frequency, RDe: relative density, RDo: relative dominance, and IVI: Species Importance Value).

\begin{tabular}{|c|c|c|c|c|}
\hline Species name & $\mathrm{Rf}$ & $\mathrm{RDe}$ & RDo & IVI \\
\hline Julbernadia globiflora (Benth.) Troupin & 3.7 & 3.5 & 6.0 & 13.3 \\
\hline Dalbergia melanoxylon Guill. and Perr. & 1.9 & 1.5 & 8.1 & 11.5 \\
\hline Brachystegia spiciformis Benth. & 3.7 & 4.0 & 3.2 & 11.0 \\
\hline Burkea Africana Hook.f. & 3.1 & 3.5 & 3.6 & 10.2 \\
\hline Synsepalum cerasiferum (Welw.) T.D. Penn. & 3.1 & 3.5 & 3.2 & 9.8 \\
\hline Albizia glaberrima (Schum. and Thonn.) Benth. & 2.5 & 2.5 & 3.2 & 8.2 \\
\hline Ophrypetalum odoratum Diels. & 2.5 & 3.0 & 2.4 & 7.9 \\
\hline Dombeya natalensis Sond. & 2.5 & 3.0 & 2.0 & 7.5 \\
\hline Ehretia amoena Klotzsch. & 1.9 & 2.5 & 2.8 & 7.1 \\
\hline Markhamia obtusifolia (Baker) Sprague. & 2.5 & 2.5 & 1.9 & 6.9 \\
\hline Vitex doniana Sweet & 3.1 & 2.5 & 1.3 & 6.9 \\
\hline Strychnos spinosa Lam. & 1.9 & 2.5 & 2.4 & 6.8 \\
\hline Bauhinia petersiana Bolle & 1.9 & 3.0 & 1.7 & 6.6 \\
\hline Acacia nigrescens Oliv. & 2.5 & 2.5 & 1.6 & 6.6 \\
\hline Dalbergia boehmii Taub. & 1.9 & 3.0 & 1.7 & 6.6 \\
\hline Stereospermum kunthianum Cham. & 2.5 & 2.5 & 1.4 & 6.4 \\
\hline Sclerocarya birrea (A.Rich.) Hochst & 2.5 & 2.5 & 1.1 & 6.1 \\
\hline Myrianthus holstii Engl. & 1.9 & 2.0 & 2.2 & 6.1 \\
\hline Diospyros squarrosa Klotzsch. & 2.5 & 2.5 & 1.1 & 6.1 \\
\hline Deinbollia borbonica Scheff. & 2.5 & 2.0 & 1.4 & 5.9 \\
\hline Albizia petersiana (Bolle) Oliv. & 1.2 & 1.5 & 3.1 & 5.9 \\
\hline Trema orientalis (L.) Blume & 2.5 & 2.0 & 1.2 & 5.7 \\
\hline Sterculia quinqueloba (Garcke) K. Schum. & 1.9 & 1.5 & 2.0 & 5.4 \\
\hline Albizia versicolor Welw. ex Oliver & 1.2 & 2.0 & 2.0 & 5.3 \\
\hline Acacia polyacantha Wild. & 1.2 & 1.5 & 2.5 & 5.2 \\
\hline Terminalia sambesiaca Engl. and Diels. & 1.2 & 2.0 & 1.8 & 5.0 \\
\hline Acacia seyal Del. & 1.2 & 1.5 & 2.2 & 5.0 \\
\hline Bridelia micrantha (Hochst.) Baill. & 1.2 & 1.0 & 2.6 & 4.8 \\
\hline Ficus lutea Vahl. & 1.9 & 1.5 & 1.3 & 4.7 \\
\hline Dombeya rotundifolia (Hochst.) Planch. & 1.9 & 1.5 & 1.1 & 4.5 \\
\hline Milicia excelsa (Welw.) C.C. Berg & 0.6 & 0.5 & 3.3 & 4.4 \\
\hline Cynometra ulugurensis Harms. & 1.2 & 1.5 & 1.5 & 4.3 \\
\hline Parkia filicoidea & 1.2 & 1.0 & 2.0 & 4.2 \\
\hline Cussonia spicata Thunb. & 1.9 & 1.5 & 0.7 & 4.1 \\
\hline Khaya anthotheca (Welw.) C. DC. & 1.2 & 1.0 & 1.6 & 3.8 \\
\hline Oncoba spinosa Forssk. & 1.2 & 1.5 & 1.0 & 3.8 \\
\hline Harungana madagascariensis Lam.ex Poiret & 0.6 & 0.5 & 2.4 & 3.6 \\
\hline Acacia caffra Thunb. Wild. & 1.2 & 1.0 & 1.2 & 3.5 \\
\hline Commiphora africana (A.Rich.) Endl. & 1.2 & 1.0 & 1.0 & 3.3 \\
\hline Combretum molle R.Br. ex G.Don. & 1.2 & 1.0 & 1.0 & 3.2 \\
\hline Brachystegia temarindoides Benth. & 1.2 & 1.0 & 0.9 & 3.1 \\
\hline Allanblackia ulugurensis Engl. & 1.2 & 1.0 & 0.7 & 3.0 \\
\hline Grewia similis K. Schum. & 1.2 & 1.0 & 0.7 & 2.9 \\
\hline Breonadia salicina (Vahl) Happer and J.R.I. Wood & 1.2 & 1.0 & 0.6 & 2.8 \\
\hline Margaritaria discoidea (Baill.) G.L. Webster & 1.2 & 1.0 & 0.5 & 2.8 \\
\hline Englerophytum natalense (Sond.) T.D. Penn. & 1.2 & 1.0 & 0.5 & 2.7 \\
\hline Anthocleista grandiflora L. & 1.2 & 1.0 & 0.4 & 2.7 \\
\hline Antiaris toxicaria Lesch. & 1.2 & 1.0 & 0.4 & 2.6 \\
\hline Ficus exasperate Vahl. & 1.2 & 1.0 & 0.4 & 2.6 \\
\hline
\end{tabular}


TABLE 2: Continued.

\begin{tabular}{|c|c|c|c|c|}
\hline Species name & $\mathrm{Rf}$ & $\mathrm{RDe}$ & RDo & IVI \\
\hline Cussonia zimmermannii Harms. & 0.6 & 0.5 & 1.1 & 2.2 \\
\hline Lonchocarpus bussei Harms. & 0.6 & 0.5 & 0.9 & 2.0 \\
\hline Cassipourea malosana Alston & 0.6 & 1.0 & 0.4 & 2.0 \\
\hline Sterculia appendiculata K. Schum. & 0.6 & 0.5 & 0.7 & 1.8 \\
\hline Pterocarpus tinctorius Welw. & 0.6 & 0.5 & 0.5 & 1.6 \\
\hline Scrodophleous fischeri (Taub.) J. Leon & 0.6 & 0.5 & 0.5 & 1.6 \\
\hline Cassia abbreviata Oliv. & 0.6 & 0.5 & 0.4 & 1.5 \\
\hline Oxyanthus goetzei K. Schum & 0.6 & 0.5 & 0.3 & 1.5 \\
\hline Harrisonia abyssinica Oliv. & 0.6 & 0.5 & 0.3 & 1.4 \\
\hline Annona senegalensis Pers. & 0.6 & 0.5 & 0.3 & 1.4 \\
\hline Combretum adenogonium Steud. ex Rich. & 0.6 & 0.5 & 0.2 & 1.3 \\
\hline Diplorhynchus condylocarpon (Muell.Arg.) Pichon & 0.6 & 0.5 & 0.2 & 1.3 \\
\hline Markhamia zanzibarica Bojer ex DC. & 0.6 & 0.5 & 0.2 & 1.3 \\
\hline Erythrophleum suaveolens (Guill and Perr) Brennan & 0.6 & 0.5 & 0.2 & 1.3 \\
\hline Commiphora eminii Engl. & 0.6 & 0.5 & 0.2 & 1.3 \\
\hline Pseudolachnostylis maprouneifolia Pax & 0.6 & 0.5 & 0.2 & 1.3 \\
\hline Tabernaemontana pachysiphon Stapf & 0.6 & 0.5 & 0.2 & 1.3 \\
\hline Pouteria altissima (A.Chev.) Baehni & 0.6 & 0.5 & 0.2 & 1.3 \\
\hline Total & 100 & 100 & 100 & 300 \\
\hline
\end{tabular}

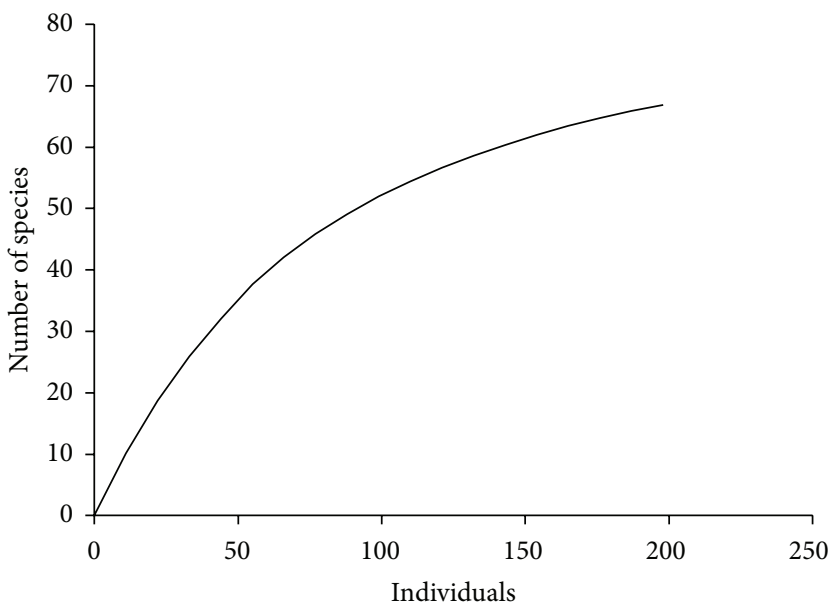

(a)

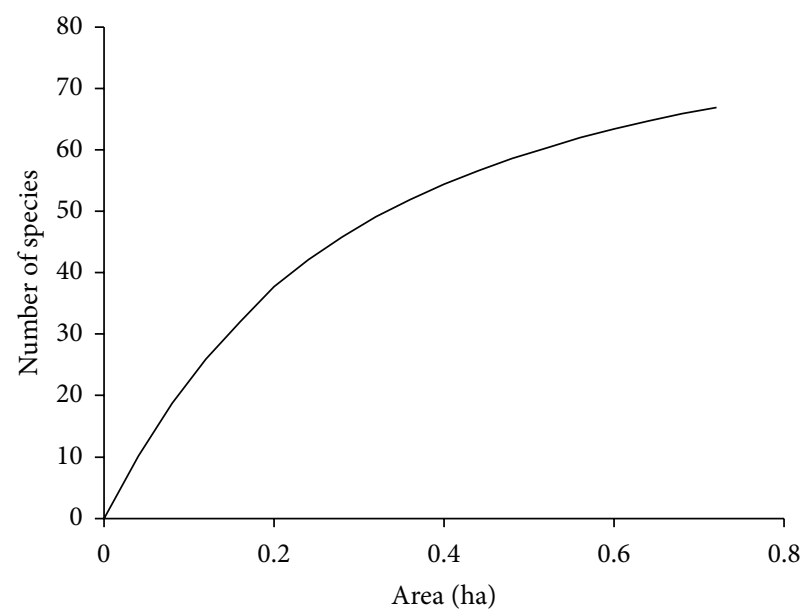

(b)

FIgURE 2: Species accumulation curves based on (a) numbers of individual trees and (b) cumulative sample area in the forest.

with up to $50 \%$ of the total richness of the area [19]. The top ten important families recorded in the present study (Table 1) were similar to those recorded in other studies [13, $16,20]$.

The IVI is commonly used in ecological studies as it shows ecological importance of a species in a given ecosystem. The IVI is also used for prioritizing species conservation whereby species with low IVI value need high conservation priority compared to the ones with high IVI $[2,21]$. The high IVI exhibited by J. globiflora is largely due to its higher relative frequency, density, and dominance compared to other species. The co-dominance of D. melanoxylon in terms of IVI is mainly due to its higher basal area or relative dominance compared to all species. The presence of many species with lower IVI values in this study is an indication that the majority of species are rare in the forest. This finding is also supported by the frequency distribution (Figure 1) and the species accumulation curves (Figure 2). The frequency distribution graph reveals $78 \%$ of the observed species to occur in less than four plots, while the accumulation curves reveal an escalating trend that indicates that the forest holds more rare species than common ones [22]. The large number of rare species encountered in this study confirms the commonly acclaimed notion that most of the species in the ecological community are rare, rather than common [11]. The rarity may be due to various reasons, which include (1) strong 
TABLE 3: Structure and diversity indices of Kilengwe Forest.

\begin{tabular}{lc}
\hline Parameter & Value \\
\hline Number of individuals/ha $(N \pm \mathrm{SE})$ & $276 \pm 35$ \\
Number of species/ha $(S \pm \mathrm{SE})$ & $93 \pm 6$ \\
$N / S$ & 2.97 \\
Shannon-Wiener's index $( \pm \mathrm{SD})$ & $4.02 \pm 0.07$ \\
Fisher's alpha $( \pm \mathrm{SD})$ & $35.5 \pm 4.3$ \\
Evenness $( \pm \mathrm{SE})$ & $0.95 \pm 0.01$ \\
MMMeans & 124 \\
Jackknife $1( \pm \mathrm{SD})$ & $86 \pm 4$ \\
Mean basal area $( \pm \mathrm{SE}) \mathrm{m}^{2} / \mathrm{ha}$ & $7.1 \pm 1$ \\
\hline
\end{tabular}

density-dependency in the forest, (2) existence of a resource gradient, which causes species to occupy different positions within it resulting in abundance distribution variation, (3) poor dispersability of species, (4) natural or anthropogenic disturbances, and (5) competition within the forest [23-25].

Both species-area and species-individual curves displayed an escalating trend, which suggest that increasing the sampling effort (i.e., area and individuals) would increase the observed species richness. This is due to the fact that the larger the forest area sampled is, the more environmentally heterogeneous the sampling area becomes. The observed trend in both curves coincide with the two used species richness estimators (Jackknife 1 and MMMeans) in Table 3, which provide higher number of species than the observed species in the forest. Also, the curves are basically informing that the sample size used was not enough to capture all the species in the forest, which imply that more plots will be required for future inventories in the forest. The lower $\mathrm{N} / \mathrm{S}$ ratio (2.97) suggests that the number of individuals of different species was low, which indicate high rarity in the studied plots [11]. The species diversity indices and evenness index revealed presence of high tree diversity and even representation of species in the studied forest compared to other forests $[2,12]$.

4.2. Forest Structure. Density, basal area, frequency distribution, and size or DBH class distributions of trees contribute to the structure of the forest. The forest density and basal area were lower by $7 \%$ and $37 \%$, respectively, compared to the values obtained by Malimbwi et al. [12]. The decline in the two parameters can be associated with increasing anthropogenic disturbances in the forest, especially logging of big trees. In Madagascar, the low basal area values in the forests were related to high accessibility by the nearby community and lack of enough protection, which could account for observed values too [26]. In any forest, lower basal area is mainly characterized by high abundance of young trees [27] and sometimes lacking individuals in the larger size class (DBH $>50 \mathrm{~cm}$ ) as observed in this study (Figure 3). In general, size class distribution of undisturbed forest or less disturbed forest should fit the reverse J-shaped pattern, with most of the trees in the smaller size classes and fewer in the larger ones [28]. The size class distributions in this study suggest that

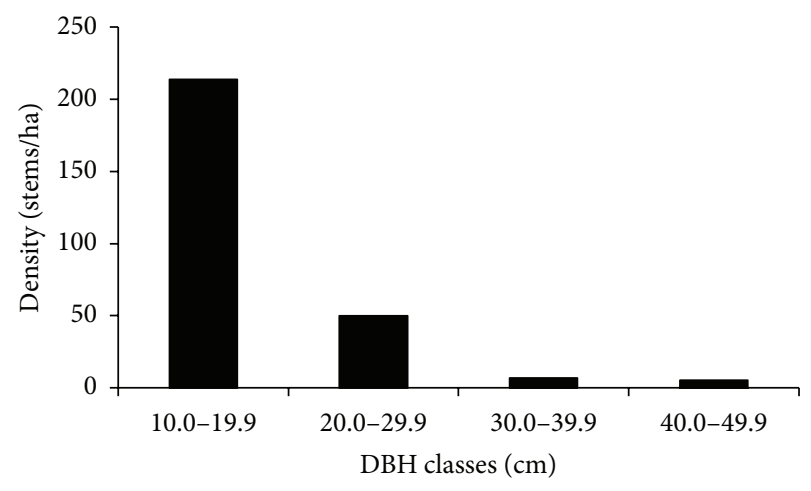

FIgURE 3: Size class distribution of the trees species recorded in the present study.

the forest is at a crucial stage of regeneration and recovering from disturbances. The lack of individuals in the larger size classes could be due to illegal logging of bigger trees by the locals for timber and construction purposes or the fact that the forest has limited species that grow larger than these diameters $[2,29]$. The species with high timber values, for instance, D. melanoxylon, M. excelsa, Pterocarpus spp., and Khaya anthotheca were observed to be logged below their minimum required harvestable diameter, which account for their low density and perhaps lack of individuals in the larger size classes that contribute to lower forest basal area. Several authors $[2,30,31]$ reported the same species to be extremely exploited in other parts of Tanzania.

The frequency class distributions showed that $78 \%$ of the total species fell in the $0 \%-10 \%$ and $10.0 \%-19.9 \%$ frequency classes whereas the higher frequency classes $>40 \%$ were not represented. Such a result suggests that most of the species had low occurrence as would be expected in a typical species-abundance distribution. Normally, a tree species is considered homogeneously distributed when the numbers of individuals are equal in all parts of the community. Thus, the frequency distribution analysis indicates the presence of high degree of floristic heterogeneity in the forest. Usually, frequency reflects the pattern of distribution and provides an approximate indication of the heterogeneity of the forest [21].

4.3. Implications for Conservation. Understanding tree species composition, diversity, and structure is a vital instrument in assessing sustainability of any forest, conservation of species, and management of the ecosystems at large $[5,16]$. This research sought to describe the current status of the forest structure, composition, and diversity of tree species community in the Kilengwe Forest. In Tanzania, conservation of biodiversity has become an issue of increasing priority and importance within the international scientific community and policy makers in the recent years. Rapid human population growth and the continuing practice of slash-and-burn clearing as an agricultural technique are two associated factors in the degradation and fragmentation of the forest habitats. The damage is irreversible and is really threatening the forest biodiversity in the country [2,5]. Kacholi [2] revealed human population density to have significant adverse impacts on 
forest size, species richness, and diversity and concluded that if human population is not controlled well, forests are likely to be fragmented and the remnants will significantly lose their ability to sustain the original biological diversity. Thus, this study suggests for the following: First, need for an immediate intervention to prevent disturbances in the forest, particularly anthropogenic (e.g. illegal timber harvest and fuelwood collection) and cattle grazing, which are major sources of the forest deterioration. Establishment of fuelwood plantation for villagers, rotational grazing, and reducing livestock numbers will help accomplish this goal as conservation measures. Second, local community needs to be practically involved by the local government (the owner) in the protection and management of the forest through a joint strategy. Third, the environmental education on the importance of forest ecosystems needs to be provided to villagers. Fourth, Both in situ and ex situ conservation methods need to be used for preserving the forest indigenous species, particularly those having low importance value index (IVI), and lastly, a series of more comprehensive forest ecosystem studies are required to provide knowledge and foundation for future research.

\section{Conflict of Interests}

The author declares that there is no conflict of interests regarding the publication of this paper.

\section{Acknowledgments}

The author is thankful to the Department of Forest in Morogoro Department for permission to access the forest transport logistics and advice when needed. Also, appreciation is extended to the Deutscher Akademischer Austausch Dienst (DAAD) for funding the project.

\section{References}

[1] L. R. Holdridge, Life Zone Ecology, Tropical Science Center, San Jose, Costa Rica, 1967.

[2] D. S. Kacholi, Effects of habitat fragmentation on biodiversity of Uluguru Mountain forests in Morogoro region, Tanzania [Ph.D. thesis submitted at Georg-August University Goettingen], Cuvillier Verlag, Goettingen, Germany, 2013.

[3] "Global forest resources assessment 2010," Main Report. FAO Paper 163, Food and Agriculture Organization of the United Nation (FAO), Rome, Italy, 2010.

[4] W. D. Newmark, Conserving Biodiversity in East African Forests. A Study of the Eastern Arc Mountains, Springer, New York, NY, USA, 2002.

[5] S. Madoffe, G. D. Hertel, P. Rodgers, B. O'Connell, and R. Killenga, "Monitoring the health of selected eastern arc forests in Tanzania," African Journal of Ecology, vol. 44, no. 2, pp. 171177, 2006.

[6] R. Condit, S. P. Hubbell, J. V. Lafrankie et al., "Species-area and species-individual relationships for tropical trees: a comparison of three 50-ha plots," Journal of Ecology, vol. 84, no. 4, pp. 549$562,1996$.
[7] A. H. Gentry, "Tropical forest biodiversity: distributional patterns and their conservational significance," Oikos, vol. 63, no. 1, pp. 19-28, 1992.

[8] S. A. Mori, B. M. Boom, A. M. Carvalho de, and T. S. Dos Santos, "Ecological importance of Myrtaceae in an Eastern Brazilian West Forest," Biotropica, vol. 15, no. 1, pp. 68-70, 1983.

[9] J. T. Curtis and R. P. McIntosh, "The interrelations of certain analytic and synthetic of phytosociological characters," Ecology, vol. 31, pp. 434-455, 1950.

[10] R. M. Seaby and P. A. Henderson, Species Diversity and Richness Version 4, Pisces Conservation, Lymington, UK, 2006.

[11] A. N. Magurran, Measuring Biological Diverisy, Blackwell Science, Melden, Germany, 2004.

[12] R. E. Malimbwi, D. Shemweta, E. Zahabu, S. P. Kingazi, J. Z. Katani, and D. A. Silayo, "Forest inventory for mvomero district, Morogoro-Tanzania," FORCONSULT Unpublished Report, 2005.

[13] E. N. Mwavu, Human impact, plant communities, diversity and regeneration in Budongo forest reserve, North-Western Uganda [Ph.D. thesis], University of the Witwatersrand, Johannesburg, South Africa, 2007.

[14] K. Z. Doody, A. Ntemi, R. Killenga, and N. K. Beharrell, "Vegetation in mpanga village forest reserve: a biodiversity survey," East Usambara Conservation Area Management Programme Technical Paper 51, Frontier Tanzania: Forestry and Beekeeping Division and Metsähallitus Consulting, Dar es Salaam, Tanzania, Vantaa, Finland, 2011.

[15] A. Gentry, "Changes in plant community diversity and floristic composition on environmental and geographical gradients," Annals of Missouri Botanical Garden, vol. 75, pp. 1-34, 1988.

[16] P. Addo-Fordjour, S. Obeng, A. K. Anning, and M. G. Addo, "Floristic composition, structure and natural regeneration in a moist-semi deciduous forest following anthropogenic disturbances and plant invasion," International Journal of Biodiversity and Conservation, vol. 1, no. 2, pp. 021-037, 2009.

[17] N. D. Burgess and C. Muir, "Coastal forests of Eastern Africa: Biodiversity and Conservation," in Proceedings of the Workshop held at the University of Dare s Salaam, Society for Environmental Exploration/Royal society for the protection of birds, Frontier, UK, August 1994.

[18] S. P. Rwamugira, Impact of mining on forest ecosystem and adjacent communities of Eastern Arc Mountains. A case study of Ruvu catchment forest reserve [M.S. thesis], Sokoine University of Agriculture, 2008.

[19] N. D. Burgess and G. P. Clarke, “The coastal forests of Eastern Africa," IUCN: Cambridge and Gland, 2000.

[20] F. Wittmann, J. Schöngart, J. C. Montero et al., “Tree species composition and diversity gradients in white-water forests across the Amazon Basin," Journal of Biogeography, vol. 33, no. 8, pp. 1334-1347, 2006.

[21] H. Zegeye, D. Teketay, and E. Kelbessa, "Diversity, regeneration status and socio-economic importance of the vegetation in the islands of Lake Ziway, South-Central Ethiopia," Flora, vol. 201, no. 6, pp. 483-498, 2006.

[22] N. J. Gotelli and R. K. Colwell, "Estimating species richness," in Biological Diversity: Frontiers and Measurement and Assessment, A. E. Magurran and B. J. McGill, Eds., Oxford University Press, New York, NY, USA, 2011.

[23] P. A. Schwarz, T. J. Fahey, and C. E. McCulloch, "Factors controlling spatial variation of tree species abundance in a forested landscape," Ecology, vol. 84, no. 7, pp. 1862-1878, 2003. 
[24] L. S. Comita, R. Condit, and S. P. Hubbell, "Developmental changes in habitat associations of tropical trees," Journal of Ecology, vol. 95, no. 3, pp. 482-492, 2007.

[25] S. P. Hubbell, J. A. Ahumada, R. Condit, and R. B. Foster, "Local neighborhood effects on long-term survival of individual trees in a neotropical forest," Ecological Research, vol. 16, no. 5, pp. 859-875, 2001.

[26] J. C. Ingram, T. P. Dawson, and R. J. Whittaker, "Mapping tropical forest structure in southeastern Madagascar using remote sensing and artificial neural networks," Remote Sensing of Environment, vol. 94, no. 4, pp. 491-507, 2005.

[27] R. Pardini, S. M. de Souza, R. Braga-Neto, and J. P. Metzger, "The role of forest structure, fragment size and corridors in maintaining small mammal abundance and diversity in an Atlantic forest landscape," Biological Conservation, vol. 124, no. 2, pp. 253-266, 2005.

[28] T. C. Whitmore, An Introduction to Tropical Rainforests, Oxford University Press, Oxford, UK, 2nd edition, 1998.

[29] S. Hadi, T. Ziegler, M. Waltert, and J. K. Hodges, “Tree diversity and forest structure in northern Siberut, Mentawai islands, Indonesia," Tropical Ecology, vol. 50, no. 2, pp. 315-327, 2009.

[30] A. Ahrends, Patterns of degradation in lowland coastal forests in coastal region Tanzania [M.S. thesis], Ernst-Moritz-Arndt University, Greifswald, Germay, 2005.

[31] R. B. Modest, S. L. S. Maganga, S. N. Hassan, S. B. Mariki, and M. Muganda, "Population structure and extraction of three commercial trees in Nguru ya Ndege forest reserve, MorogoroTanzania," Ethiopian Journal of Environmental Studies and Management, vol. 3, no. 3, pp. 41-48, 2010. 

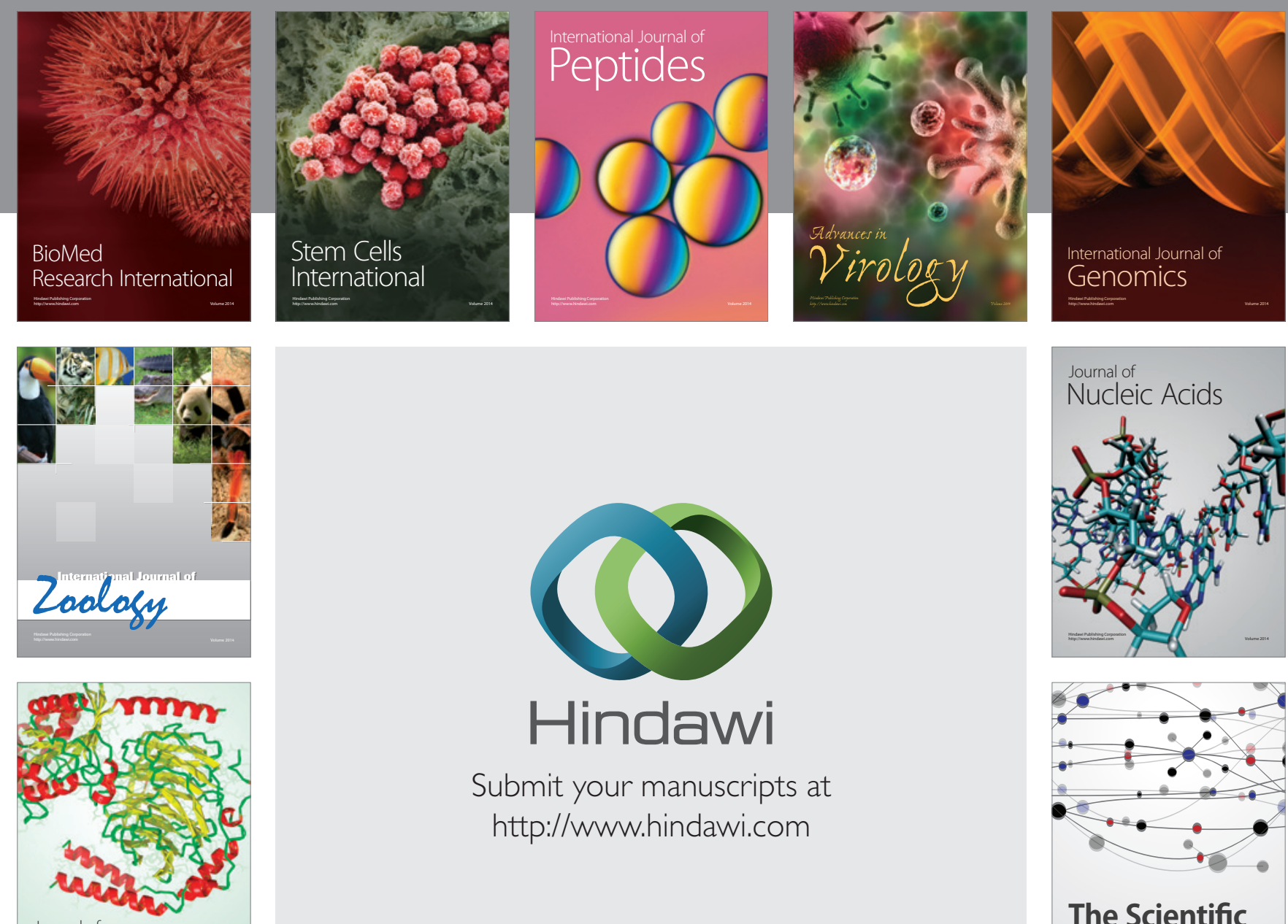

Submit your manuscripts at

http://www.hindawi.com

Journal of
Signal Transduction
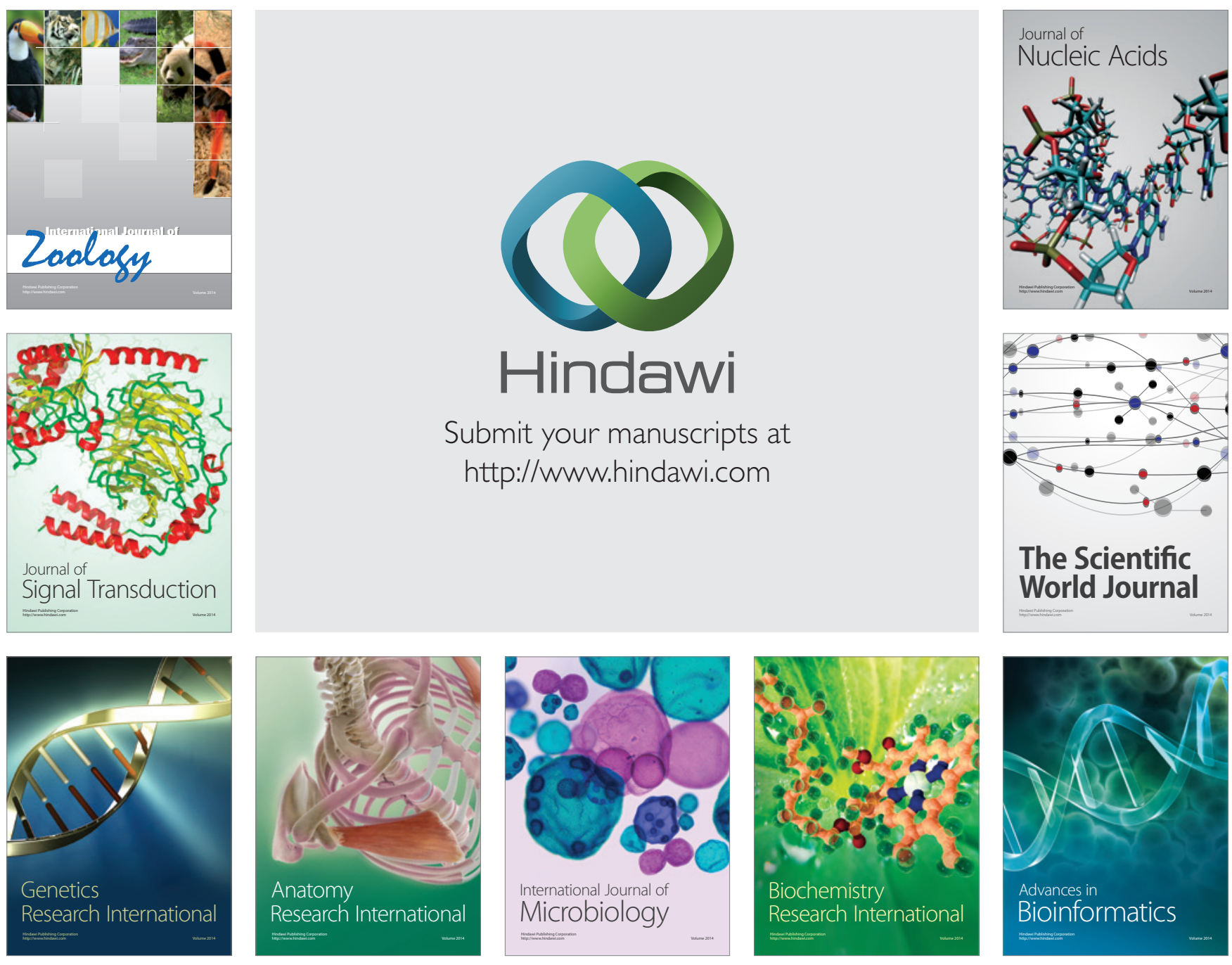

The Scientific World Journal
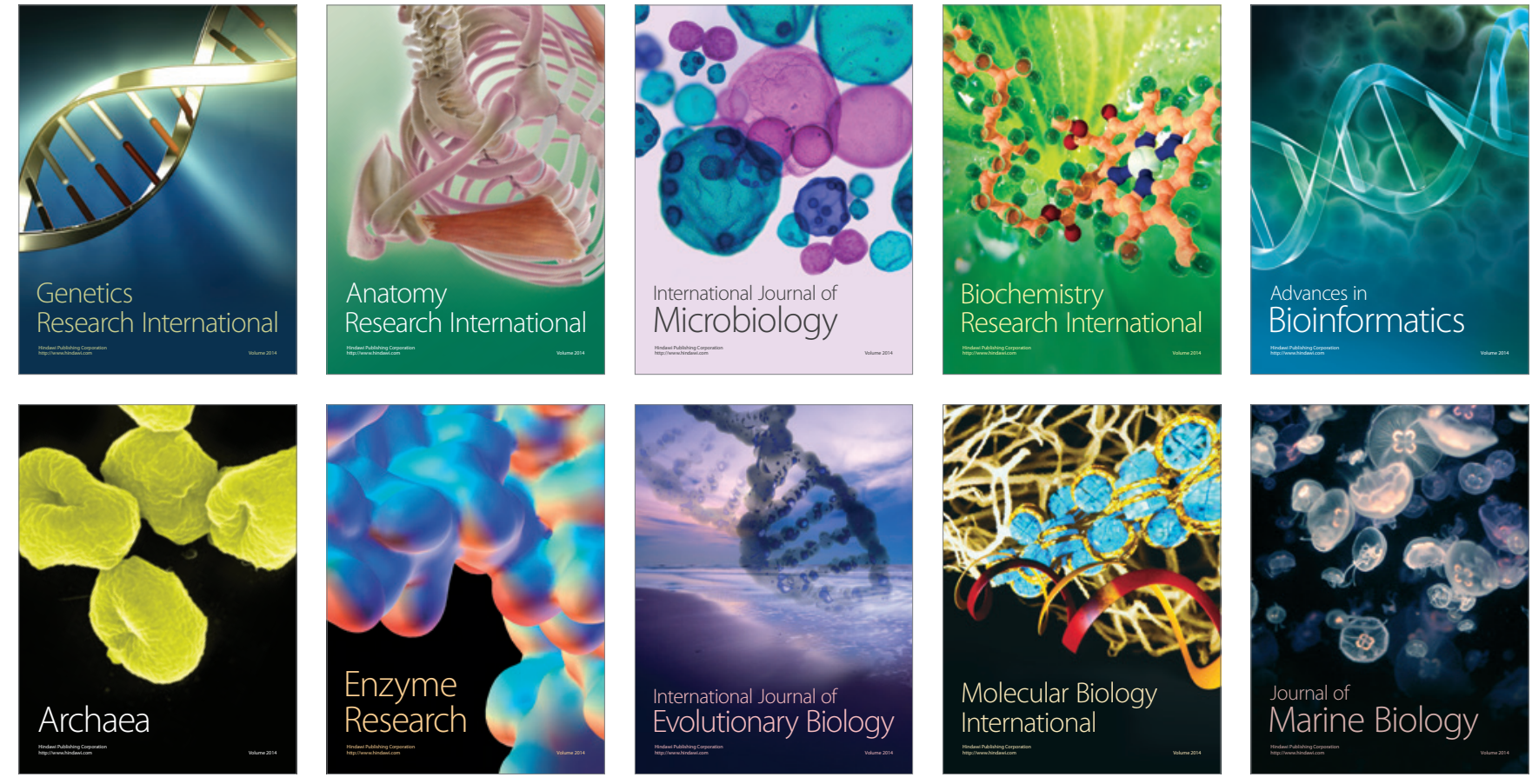